\title{
Exogenous Glycine Betaine Ameliorates the Adverse Effect of Salt Stress on Perennial Ryegrass
}

\author{
Longxing $\mathrm{Hu}$ and Tao $\mathrm{Hu}$ \\ Key Laboratory of Plant Germplasm Enhancement and Specialty Agriculture, Wuhan Botanical \\ Garden, The Chinese Academy of Science, Wuhan City, Hubei, 430074, P.R. China \\ Xunzhong Zhang \\ Virginia Polytechnic Institute and State University, Blacksburg, VA 24061 \\ Huancheng Pang \\ Institute of Agricultural Resources and Regional Planning, the Chinese Academy of Agricultural \\ Sciences, Beijing, 100081, P.R. China \\ Jinmin $\mathbf{F u}^{\mathbf{1}}$ \\ Key Laboratory of Plant Germplasm Enhancement and Specialty Agriculture, Wuhan Botanical \\ Garden, The Chinese Academy of Science, Wuhan City, Hubei, 430074, P.R. China
}

\begin{abstract}
AdDitional INDEX wORDs. antioxidant enzymes, glycine betaine, ion homeostasis, perennial ryegrass, salt stress
ABstract. Salinity stress may involve the accumulation of glycine betaine (GB). The objective of this study was to examine whether exogenous GB would ameliorate the detrimental effect of salinity stress on perennial ryegrass (Lolium perenne). The grass was subjected to two salinity levels ( 0 and $250 \mathrm{~mm} \mathrm{NaCl})$ and three $\mathrm{GB}$ levels $(0,20$, and 50 mM). Salinity resulted in a remarkable decrease in vertical shoot growth rate (VSGR), shoot and root fresh weight, relative water content (RWC), relative transpiration rate (Tr), and chlorophyll (Chl) content, superoxide dismutase (SOD), catalase (CAT), and ascorbate peroxidase (APX) activities. Plants subjected to salt exhibited an increase in leaf electrolyte leakage (EL), lipid peroxidation (MDA), and proline content. Application of GB reduced EL, MDA, and proline content in salt-stressed plants. Perennial ryegrass subjected to salt stress plus GB had a greater level of VSGR, RWC, relative Tr, Chl content, and activities of SOD, CAT, and APX when compared with salt-stressed without GB. Salt stress increased $\mathrm{Na}^{+}$and decreased $\mathrm{K}^{+}$content, which resulted in a higher $\mathrm{Na}^{+} / \mathrm{K}^{+}$ratio in perennial ryegrass. Application of $20 \mathrm{~mm}$ GB suppressed $\mathrm{Na}^{+}$accumulation, whereas the $\mathrm{K}^{+}$content was significantly increased in shoot, which led to a higher $\mathrm{K}^{+} / \mathrm{Na}^{+}$ratio under saline conditions. These results suggested that GB-enhanced salt tolerance in perennial ryegrass was mainly related to the elevated SOD, CAT, and APX activity and alleviation of cell membrane damage by reducing oxidation of membrane lipid and improving the ion homeostasis under salt stress.
\end{abstract}

Salinity stress is one of the common abiotic stresses that can directly or indirectly affect the physiological status of plants by disturbing their metabolism and inhibiting root and shoot growth (Zhu, 2001). Previous studies have shown that salt stress may induce osmotic and oxidative stress in plants, which leads to cellular adaptive responses such as the accumulation of compatible organic solutes and detoxification of reactive oxygen species (ROS) (Zhu, 2001).

Salt stress inhibited the growth of most plants as a result of the overproduction of ROS such as superoxide radical $\left(\mathrm{O}_{2}{ }^{-}\right)$, hydrogen peroxide $\left(\mathrm{H}_{2} \mathrm{O}_{2}\right)$, singlet oxygen $\left({ }^{1} \mathrm{O}_{2}\right)$, and hydroxyl radical $\left(\mathrm{OH}^{-}\right)($Mittler, 2002). ROS are formed as byproducts of normal cellular metabolism and necessary for enzymatic reactions of inter- and intracellular signaling when plants are exposed to a low level of salinity stress (Foyer and Noctor, 2000). However, severe salinity stress could lead to an overproduction of ROS, which resulted in cellular damage through oxidation of membrane lipids, protein, and nucleic acids (Apel

Received for publication 31 Oct. 2011. Accepted for publication 13 Dec. 2011. This research was financially supported by the Knowledge Innovation Key Program (Grant No. 092A281X02) of the Chinese Academy of Sciences and the Special Fund of Industrial (Agriculture) Research for Public Welfare of China (200903001)

${ }^{1}$ Corresponding author. E-mail: jinminfu@gmail.com. and Hirt, 2004). To alleviate detrimental effects of salt-induced oxidative stress, plant cells have evolved a complex antioxidant system (e.g., enzymatic and nonenzymatic detoxification mechanisms). Antioxidant enzymes consisted of superoxide dismutase, catalase, peroxidase (POD), ascorbate peroxidase, etc. (Apel and Hirt, 2004). SOD catalyzes the dismutation of $\mathrm{O}_{2}^{-}$to molecular $\mathrm{O}_{2}$ and $\mathrm{H}_{2} \mathrm{O}_{2}$ (Meloni et al., 2003). However, $\mathrm{H}_{2} \mathrm{O}_{2}$ is also toxic to cells and has to be further detoxified by CAT and/or POD or detoxified in the ascorbate-glutathione cycle, which involves the oxidation and re-reduction of ascorbate and glutathione through the APX (Mittler, 2002). Hoque et al. (2007) reported that exogenous glycine betaine mitigated the detrimental effects of salt stress on tobacco (Nicotiana tabacum 'Bight Yellow-2') suspension-cultured cells by maintaining or increasing the activity of antioxidant enzymes involved in $\mathrm{NaCl}$-induced oxidative stress.

Environmental stresses including salinity can induce a significant accumulation of compatible solutes (Bohnert et al., 1995). Glycine betaine is one of several such compatible solutes that has an osmoprotective function and is known to improve salt stress tolerance in most crop plants (Demiral and Türkan, 2006; Hossain and Fujita, 2010; Yang and Lu, 2005). The mechanisms of GB-improved salt tolerance in plants have been attributed to the acceleration of ROS scavenging systems, protection of membrane integrity, activation of enzymes, and reduction in oxidation of membrane lipid under salt stress 
(Demiral and Türkan, 2006). In addition, exogenous GB may have also contributed to the improvement of plant salt tolerance through its role in ion homeostasis and $\mathrm{Na}^{+} / \mathrm{K}^{+}$discrimination under salinity conditions (Hamdia and Shaddad, 2010). It has been shown that a low concentration of exogenous GB is very efficient in reducing the $\mathrm{K}^{+}$loss in barley (Hordeum vulgare) and arabidopsis (Arabidopsis thaliana) (Cuin and Shabala, $2005,2007)$ and in maintaining higher $\mathrm{K}^{+}$concentration in rice (Oryza sativa) seedlings under salinity conditions (Rahman et al., 2002). The naturally synthesized/accumulated GB is not enough to ameliorate osmotic stress caused by various environmental stresses, including salt stress for many plant species (Sakamoto and Murata, 2002; Subbarao et al., 2001). Exogenous application of GB is being successfully used to ameliorate salt stress in low GB-accumulating/non-accumulating maize (Zea mays) plants (Yang and Lu, 2005). Positive effects of exogenous GB on the growth of salt-stressed plants have been investigated in wheat (Triticum aestivum) (Raza et al., 2007), kidney beans (Phaseolus vulgaris) (Lopez et al., 2002), tomato (Solanum lycopersicum), and turnip rape (Brassica rapa) (Mäkelä et al., 1999). In contrast, Heuer (2003) observed negative effects of exogenous GB on growth of tomato. However, how GB improves salinity stress resistance in perennial grasses has not been well understood. Perennial ryegrass is one of the most important grass species in temperate climates in the world. It is not only a forage species with high yield and good quality, but also a cool-season turf species suitable for home lawns, parks, cemeteries, roadsides, golf courses, and other places.

In this study, the effect of exogenously applied GB on the ability of perennial ryegrass plants to withstand $\mathrm{NaCl}$ stress was investigated; we tested the hypothesis that GB can alleviate the detrimental effect of salt stress on perennial ryegrass through the modulation of antioxidant capacity, maintenance of $\mathrm{K}^{+}$ homeostasis by preventing $\mathrm{NaCl}$-induced $\mathrm{K}^{+}$leakage, and protection of membrane integrity by reducing lipid peroxidationlinked membrane deterioration.

\section{Materials and Methods}

Plant materials and growth conditions. Seeds of perennial ryegrass 'Quickstart II' were sowed in disposable plastic cups $(6.8 \mathrm{~cm}$ upper diameter, $4.8 \mathrm{~cm}$ lower diameter, $7.4 \mathrm{~cm}$ height) filled with sand. A drainage hole (5 $\mathrm{mm}$ diameter) was drilled at the bottom of each cup to allow drainage of excess water and soil aeration. After germination, the seedlings were watered daily with half-strength Hoagland nutrient solution (Hoagland and Arnon, 1950). Forty-five-day-old seedlings were transplanted into 250 -mL Erlenmeyer flasks filled with half-strength Hoagland's nutrient solutions with $\mathrm{CaO}_{2}$, which provided oxygen, and refilled the reservoir with fresh nutrient solution every week. The flasks were sealed with preservative film and wrapped with silicon rubber to prevent the escape of water and with aluminum foil to prevent potential growth of algae. All flasks were placed in a climate-controlled walk-in growth room with a constant temperature of $21.0 \pm 0.5^{\circ} \mathrm{C}$, a 14-h photoperiod, and a photosynthetically active radiation of $240 \mu \mathrm{mol} \cdot \mathrm{m}^{-2} \cdot \mathrm{s}^{-1}$ at the canopy level. The plant-flask system was weighed to determine water loss (i.e., transpiration rate) before the start of treatment by using the water balance method described by $\mathrm{Fu}$ et al. (2004). Plants with similar $\mathrm{Tr}$ were grouped in one replicate for salt and GB treatment, and the average $\operatorname{Tr}$ of four replicated for all the treatments was as the same level. The grass was hand-clipped three times weekly at $\approx 6 \mathrm{~cm}$ height. Plants were maintained in the mentioned conditions for $14 \mathrm{~d}$ to allow for the recovery of uptake capabilities of roots and leaves before starting salt and GB treatment.

Treatments and eXperiment Design. Perennial ryegrass was subjected to two salinity levels $(0$ and $250 \mathrm{~mm} \mathrm{NaCl})$ and three GB levels $(0,20$, and $50 \mathrm{~mm})$. The six treatments were as follows: 1) nutrient solution (control); 2) $20 \mathrm{~mm} \mathrm{~GB}$; 3) $50 \mathrm{~mm} \mathrm{~GB}$; 4) $250 \mathrm{~mm} \mathrm{NaCl}$; 5) $250 \mathrm{~mm} \mathrm{NaCl}+20 \mathrm{~mm} \mathrm{~GB}$; and 6) $250 \mathrm{~mm}$ $\mathrm{NaCl}+50 \mathrm{~mm} \mathrm{~GB} . \mathrm{NaCl}$ and GB were dissolved in half-strength Hoagland's nutrient solution. The $\mathrm{NaCl}$ solution was increased as the concentration of 80-, 160-, and 250-mm increments at 24-h intervals, and maintained the final concentration of $250 \mathrm{~mm}$ for $7 \mathrm{~d}$, and then both shoots and root were harvested for physiological analysis. The salt and/or GB treatment was arranged in a randomized, complete block design with four replicates.

Measurements. Vertical shoot growth rate was estimated by measuring the difference in average turf canopy height before and after treatment using a ruler according to the method described by Huang and Liu (2009) with slight modifications. The ruler was placed in three different areas of the canopy and brought to rest on the brim of the flask. Canopy height was measured as the average height of plants in each container. At the end of the experimental period (7 d), shoots and roots were harvested separately and fresh weights were weighed.

To determine transpiration rate, flasks including plants were weighed at the beginning of the study. After $24 \mathrm{~h}$, the flasks were weighed again to determine water loss (i.e., Tr) using the water balance method described by $\mathrm{Fu}$ et al. (2004). This procedure was repeated every $24 \mathrm{~h}$ during the study period. To compare the effect of $\mathrm{NaCl}$ and/or $\mathrm{GB}$ on plants with different initial $\mathrm{Tr}$ (before the $\mathrm{NaCl}$ and $\mathrm{GB}$ were added), the water loss is expressed as relative $\operatorname{Tr}$. The $\operatorname{Tr}$ was normalized with respect to the initial $\operatorname{Tr}$ and with respect to the $\operatorname{Tr}$ of the non-treated control. The normalized relative $\operatorname{Tr}$ was calculated using the following equation according to Yu et al. (2008):

$$
\operatorname{Tr}(\mathrm{C}, \mathrm{t})(\%)=\frac{(1 / n) \sum_{i=1}^{n} \operatorname{Ti}(C, t) / \operatorname{Ti}(C, 0)}{(1 / m) \sum_{j=1}^{m} T j(C, t) / T j(C, 0)} \times 100,
$$

where $\mathrm{C}$ is concentration (mM), $\mathrm{t}$ is time period (days), $\mathrm{T}$ is absolute $\operatorname{Tr}$ (grams per day), $\mathrm{i}$ is replicate $1,2, \ldots, \mathrm{n}$, and $\mathrm{j}$ is control $1,2, \ldots, \mathrm{m}$. The relative Tr of controls is always set at $100 \%$.

Leaf relative water content was determined using fully expanded leaves $(\approx 0.15 \mathrm{~g})$ per flask according to Barrs and Weatherly (1962). Fully expanded leaves were detached and immediately weighed to determine fresh weight $(\mathrm{FW})$. Leaf samples were soaked in the tubes with distilled water at $4{ }^{\circ} \mathrm{C}$ for $\approx 24 \mathrm{~h}$. The leaf samples were blotted dry with paper towels and weighed to determine turgid weight (TW). Leaf tissue was then dried in an oven at $80{ }^{\circ} \mathrm{C}$ to a constant dry weight (DW). Leaf RWC was calculated as $(\mathrm{FW}-\mathrm{DW}) /(\mathrm{TW}-\mathrm{DW}) \times 100$.

Cell membrane stability was determined as electrolyte leakage. To determine EL, $0.1 \mathrm{~g}$ of fully expanded leaves was washed three times with deionized water. The washed leaves were cut to $\approx 0.5$-cm long segments and incubated in $15 \mathrm{~mL}$ deionized water on a shaker for $24 \mathrm{~h}$. The initial conductance $\left(C_{i}\right)$ of the incubation solution was measured using a conductance meter (JENCO-3173; Jenco Instruments, San Diego, CA). Leaf tissue in the incubation solution was killed in an 
autoclave at $120{ }^{\circ} \mathrm{C}$ for $30 \mathrm{~min}$. The conductance of the incubation solution with killed tissues $\left(C_{\max }\right)$ was determined after a 24-h incubation on a shaker at room temperature. Relative EL was calculated as $\left(C_{\mathrm{i}} / C_{\max }\right) \times 100$.

Leaf chlorophyll content was measured by soaking $\approx 0.1 \mathrm{~g}$ of fresh leaves in $15 \mathrm{~mL}$ of dimethyl sulfoxide in the dark for $72 \mathrm{~h}$ following the procedure described by Hiscox and Israelstam (1979). The absorbance of leaf extracts at 663 and $645 \mathrm{~nm}$ was measured with a spectrophotometer [ultraviolet-2600; UNICO (Shanghai) Instruments, Shanghai, China]. Chlorophyll content was calculated based on the absorbance at 663 and $645 \mathrm{~nm}$ using the formulas described by Hiscox and Israelstam (1979): Chl $($ milligrams per gram DW $)=\left(20.2 \times \mathrm{OD}_{645}+8.02 \times \mathrm{OD}_{663}\right) \times$ $\mathrm{V} / \mathrm{DW}$, where $\mathrm{OD}=$ optical density at 645 and $663 \mathrm{~nm}, \mathrm{~V}=$ final volume (milliliters), and DW = tissue DW (grams).

For the assays of SOD, CAT, APX, and MDA, fully expanded leaves $(0.3 \mathrm{~g} \mathrm{FW})$ were homogenized in $4 \mathrm{~mL}$ of $50 \mathrm{~mm}$ ice-cold phosphate buffer $(\mathrm{pH} 7.0)$ with a pre-chilled mortar and pestle. The homogenate was centrifuged at 15,000 $g_{\mathrm{n}}$ for $15 \mathrm{~min}$ at $4{ }^{\circ} \mathrm{C}$. The supernatant was collected to determine soluble protein, enzyme activities, and MDA content. Protein content was determined using the method of Bradford (1976). Briefly, $30 \mu \mathrm{L}$ of protein samples was mixed with $3 \mathrm{~mL}$ of Bradford solution and the absorbance was measured at $595 \mathrm{~nm}$ after allowing each sample to incubate at room temperature for $5 \mathrm{~min}$ and done within $1 \mathrm{~h}$ using a spectrophotometer (ultraviolet-2600). Bovine serum albumin was used as a standard.

The activity of SOD was determined using the method described by Fu and Huang (2001). The reaction solution (3 $\mathrm{mL})$ contained $50 \mu \mathrm{M}$ of NBT, $1.3 \mu \mathrm{M}$ of riboflavin $(7,8-$ dimethyl-10-ribitylisoalloxazine), $13 \mathrm{~mm}$ of methionine, $75 \mathrm{nM}$ of ethylene diaminetetra acetic acid (EDTA), $50 \mathrm{~mm}$ of phosphate buffer ( $\mathrm{pH} 7.8$ ), and $100 \mu \mathrm{L}$ of enzyme extract with non-enzyme solution as control. A $50-\mathrm{mL}$ beaker containing the reaction medium was illuminated under a set of $40-\mathrm{W}$ fluorescent tubes (Philips, Amsterdam, The Netherlands) for 20 min. The absorbance of the irradiated solution at $560 \mathrm{~nm}$ was determined with a spectrophotometer (ultraviolet-2600). SOD activity was defined as the amount of SOD required to cause $50 \%$ inhibition of the rate of NBT reduction at $560 \mathrm{~nm}$.

Catalase activity was measured using the method of Chance and Maehly (1955). The reaction solution $(3 \mathrm{~mL})$ contained 50 mM of phosphate buffer ( $\mathrm{pH} 7.0$ ), $15 \mathrm{mM}^{\circ} \mathrm{H}_{2} \mathrm{O}_{2}$, and $100 \mu \mathrm{L}$ of enzyme extract. Reaction was initiated by adding the enzyme extract. Because of the linear decline of absorbance at $240 \mathrm{~nm}$ within the first $3 \mathrm{~min}$, changes of the absorbance were read every minute. One unit CAT activity was defined as the absorbance change of 0.01 units per minute.

Ascorbate peroxidase activity was estimated by monitoring the decline in absorbance at $240 \mathrm{~nm}$ according to Nakano and Asada (1981) with some modifications. Briefly, the $3 \mathrm{~mL}$ reaction medium contained $100 \mathrm{~mm}$ of HOAc-NaOAc buffer $(\mathrm{pH}$ 5.8), $3 \mu \mathrm{M}$ of EDTA, $10 \mathrm{~mm}$ of ascorbic acid, $5 \mathrm{~mm}$ of $\mathrm{H}_{2} \mathrm{O}_{2}$, and $100 \mu \mathrm{L}$ of enzyme extract. One unit APX activity was expressed as the absorbance change of 0.01 units per minute.

The content of MDA was determined using the method described by Dhindsa et al. (1981). One milliliter of extract was added to a tube containing $1 \mathrm{~mL}$ of $20 \%(\mathrm{v} / \mathrm{v})$ trichloroacetic acid and $0.5 \%(\mathrm{v} / \mathrm{v})$ of thiobarbituric acid. The mixture was heated in a $95{ }^{\circ} \mathrm{C}$ water bath for $30 \mathrm{~min}$, cooled to room temperature, and centrifuged at $10,000 \mathrm{~g}_{\mathrm{n}}$ for $10 \mathrm{~min}$. The supernatant was read for absorbance at 532 and $600 \mathrm{~nm}$. The absorbance for nonspecific absorption at $600 \mathrm{~nm}$ was subtracted from the value at $532 \mathrm{~nm}$. The content of MDA was calculated using the adjusted absorbance and the extinction coefficient of $155 \mathrm{~mm}^{-1} \cdot \mathrm{cm}^{-1}$ (Heath and Packer, 1968).

Free proline content was determined according to the method described by Bates et al. (1973). Fully expanded leaves $(\approx 0.2 \mathrm{~g})$ were extracted with $5 \mathrm{~mL}$ of $3 \%(\mathrm{w} / \mathrm{v})$ sulphosalicylic acid. For $2-\mathrm{mL}$ extracts, $2 \mathrm{~mL}$ of $2.5 \%$ ninhydrin $(\mathrm{w} / \mathrm{v})$ and $2 \mathrm{~mL}$ of glacial acetic acid were added and incubated for $1 \mathrm{~h}$ in a boiling water bath followed by an ice bath. To this $4 \mathrm{~mL}$ of toluene was added and mixed vigorously until the chromophore phase aspirated from the aqueous phase. The absorbance was read at $520 \mathrm{~nm}$ using a spectrophotometer (ultraviolet-2600) and calculated as micromoles per gram FW against standard proline.

Glycine betaine was determined in roots, stems, and leaves following the method of Grieve and Grattan (1983) with some modifications. Samples from each flask were collected after $7 \mathrm{~d}$ of treatment, washed three times with distilled water, and dried at $80{ }^{\circ} \mathrm{C}$ to constant weight. Glycine betaine was extracted from the dry tissue material $(\approx 0.15 \mathrm{~g})$ with distilled water. The extract $(1 \mathrm{~mL})$ was mixed with $1 \mathrm{~mL}$ of $2 \mathrm{~N} \mathrm{H}_{2} \mathrm{SO}_{4}$ and $0.4 \mathrm{~mL}$ of potassium tri-iodide solution and was kept in $4{ }^{\circ} \mathrm{C}$ for $24 \mathrm{~h}$ and followed by centrifugation at $15,000 \mathrm{~g}_{\mathrm{n}}$ at $0{ }^{\circ} \mathrm{C}$ for $15 \mathrm{~min}$. The supernatant was carefully aspirated with a fine-tipped glass tube and the periodide crystals were dissolved in $9 \mathrm{~mL}$ of 1 , 2-dichloroethane; after $2 \mathrm{~h}$, absorbance was measured spectrophotometrically at $365 \mathrm{~nm}$ (ultraviolet-2600). The GB content (milligrams per gram DW) was determined from a standard curve prepared using glycine betaine as the standard.

For $\mathrm{Na}^{+}$and $\mathrm{K}^{+}$determination, the plant materials (leaves, stems, and roots) were dried in an oven at $80{ }^{\circ} \mathrm{C}$, finely ground, and passed through a 2-mm mesh sieve. Samples were digested in $5 \mathrm{~mL}$ of $98 \% \mathrm{H}_{2} \mathrm{SO}_{4}$ and $3 \mathrm{~mL}$ of $30 \% \mathrm{H}_{2} \mathrm{O}_{2}$ for $5 \mathrm{~h}$. The $\mathrm{Na}^{+}$ and $\mathrm{K}^{+}$content of the mineral extract were determined using a flame photometer.

Statsistical analysis. All data were subjected to analysis of variance according to the general linear model procedure of SAS (SAS Institute, Cary, NC) to determine the effects of salinity, GB, and their interactions. Treatment means were separated using the least significant difference test at the $P=$ 0.05 level of probability.

\section{Results}

The salt treatment $(250 \mathrm{~mm} \mathrm{NaCl})$ reduced plant vertical shoot growth rate regardless of GB treatment (Table 1). When averaged over three GB treatments, salt stress reduced VSGR by $41.8 \%$ when compared with the control. The plants treated with GB at 20 or $50 \mathrm{~mm}$ had higher VSGR under salinity stress when compared with the plants not treated with GB. However, addition of GB reduced VSGR of the plants not exposed to salt stress. A greater reduction was observed in $50 \mathrm{~mm}$ GB relative to $20 \mathrm{~mm} \mathrm{~GB}$ treatment (Table 1).

As shown in Figure 1A-B, the salt treatment alone reduced shoot and root FW when compared with the control. The GB treatment significantly alleviated decline in shoot and root weight induced by salt stress. The salt-stressed plants treated with GB exhibited higher shoot and root fresh weight when compared with those without GB treatment. The GB treatment did not affect root FW under non-salinity conditions, whereas GB application at $20 \mathrm{~mm}$ increased shoot FW (Fig. 1B). 
Salt stress reduced leaf RWC (Table 1). Application of GB alleviated the decline of RWC resulting from salt stress (Table 1). There was no significant change in leaf RWC among the three GB application levels under non-salinity conditions.

Salt stress reduced relative $\operatorname{Tr}$ (Fig. 2). Application of GB at 20 mm significantly increased the relative Tr within the first 3 to $4 \mathrm{~d}$ of treatment under either non-salinity or salt-stressed conditions. Exogenous application of the higher concentration of GB (50 mM) was more effective in depressing the relative Tr of both salt-stressed and non-stressed plants than the lower concentration of GB [20 mm (Fig. 2)].

Salt stress reduced leaf $\mathrm{Chl}$ content relative to the control (Fig. 3). Addition of GB alleviated Chl decline in salt-stressed

Table 1. Effect of glycine betaine (GB) on vertical shoot growth rate (VSGR) and leaf relative water content (RWC) of perennial ryegrass under salt-stressed or non-stressed conditions. ${ }^{\mathrm{z}}$

\begin{tabular}{|c|c|c|c|c|}
\hline \multirow{3}{*}{$\begin{array}{l}\text { GB treatment } \\
(\mathrm{mM})\end{array}$} & \multicolumn{4}{|c|}{$\mathrm{NaCl}$ treatment $(\mathrm{mm})$} \\
\hline & 0 & 250 & 0 & 250 \\
\hline & \multicolumn{2}{|c|}{ VSGR $\left(\mathrm{cm} \cdot \mathrm{d}^{-1}\right)$} & \multicolumn{2}{|c|}{ RWC (\%) } \\
\hline 0 & $2.0 \mathrm{aA}^{\mathrm{y}}$ & $0.8 \mathrm{bB}$ & $95.8 \mathrm{aA}$ & $78.3 \mathrm{bB}$ \\
\hline 20 & $1.4 \mathrm{aB}$ & $1.0 \mathrm{bA}$ & $96.5 \mathrm{aA}$ & $91.0 \mathrm{bA}$ \\
\hline 50 & $1.2 \mathrm{aC}$ & $0.9 \mathrm{bA}$ & $96.0 \mathrm{aA}$ & 89.9 bA \\
\hline
\end{tabular}

${ }^{\mathrm{z}}$ Data are expressed as means of four replicates $(n=4)$.

${ }^{y}$ Means in a column followed by the same upper-case letter for each measurement are not significant; means in a row followed the same lower-case letters for each measurement are not significant at Fisher's protected least significant difference test at $P=0.05$.
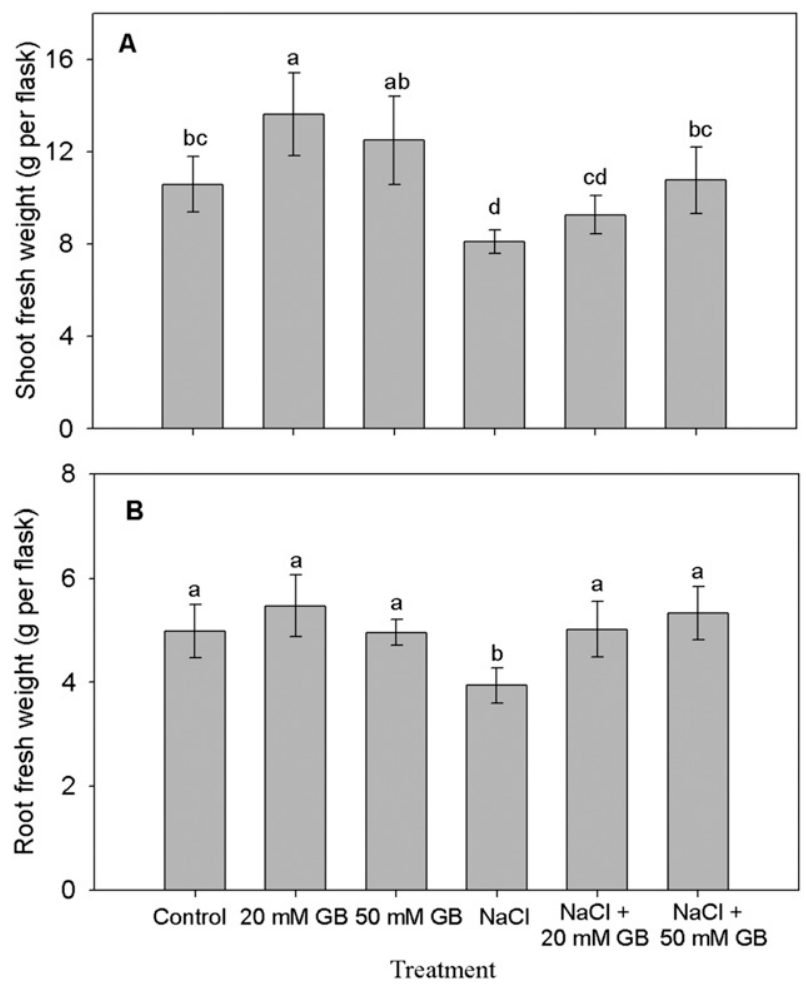

Fig. 1. Effects of glycine betaine (GB) on fresh weight of shoot (A) and root (B) in perennial ryegrass under salt stress or non-stress conditions. The concentration of $\mathrm{NaCl}$ was $250 \mathrm{~mm}$. Plants fresh weight was measured after $7 \mathrm{~d}$ of treatment. Vertical bars on the top indicate SD, and bars with the same letter indicate no significant difference at $P=0.05$. plants. Application of GB did not affect Chl content under nonsalinity conditions (Fig. 3).

Leaf EL and MDA levels were generally used to assess the extent of membrane damage caused by environmental stress. As shown in Figure 4A-B, salt stress caused a significant increase in leaf EL and MDA content. Application of GB reduced EL and MDA content in salt-stressed plants when compared with those not treated with GB. Exogenous GB did not affect on EL and MDA content under non-salinity conditions.

Salt treatment with or without the addition of GB resulted in an increase in leaf proline content when compared with the control or GB treatment alone (Fig. 5). Application of salt plus $\mathrm{GB}$ at 20 and $50 \mathrm{~mm}$ reduced proline content by $13 \%$ and $19 \%$, respectively, when compared with salt treatment alone. No significant difference among the three GB application levels was observed under non-salinity conditions.

Salt stress increased endogenous GB content in both leaves and stems but not in roots when compared with the control (Table 2). Exogenous GB treatments increased endogenous GB content in both salt-stressed and non-stressed plants, except for GB treatment at $20 \mathrm{~mm}$, which did not leaf with GB under salt stress conditions. Application of GB at $50 \mathrm{~mm}$ caused a greater accumulation of GB in the leaves, stems, and roots than GB treatment at 0 or $20 \mathrm{~mm}$. The GB content was lower in roots than

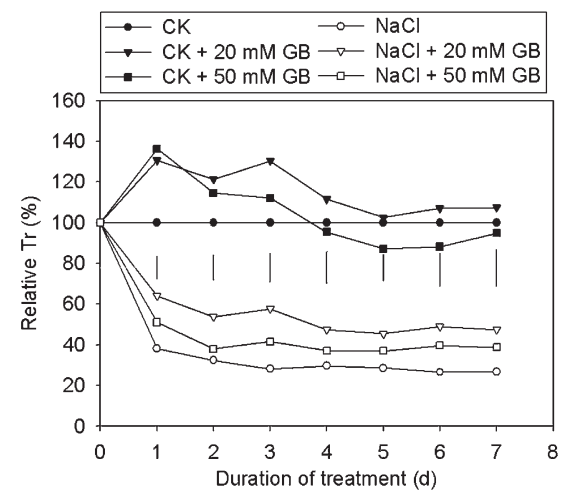

Fig. 2. Relative transpiration rate ( $\mathrm{Tr}$ ) of perennial ryegrass subjected to different levels of glycine betaine (GB) applied to salt-stressed or non-stressed plants. Vertical bars indicate least significant difference values $(P=0.05)$ for the comparison of treatment at a given day.

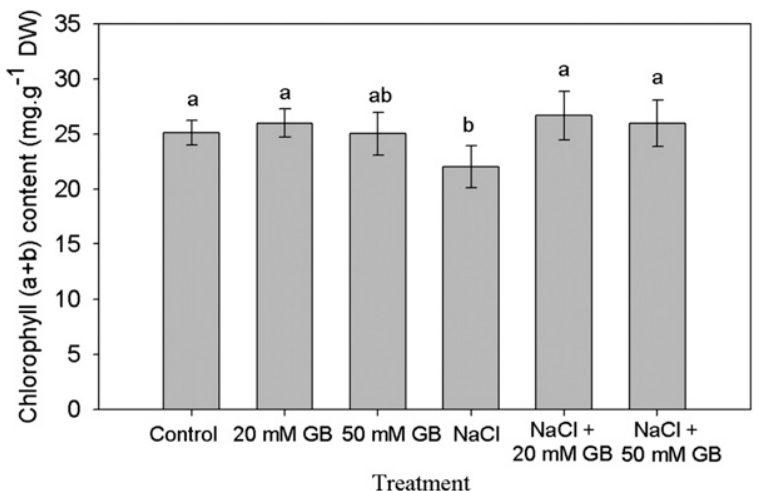

Fig. 3. Effects of glycine betaine (GB) on chlorophyll (Chl) content of perennial ryegrass under salt stress or non-stress conditions. Vertical bars on the top indicate SD, and bars with the same letter indicate no significant difference at $P=0.05$. 

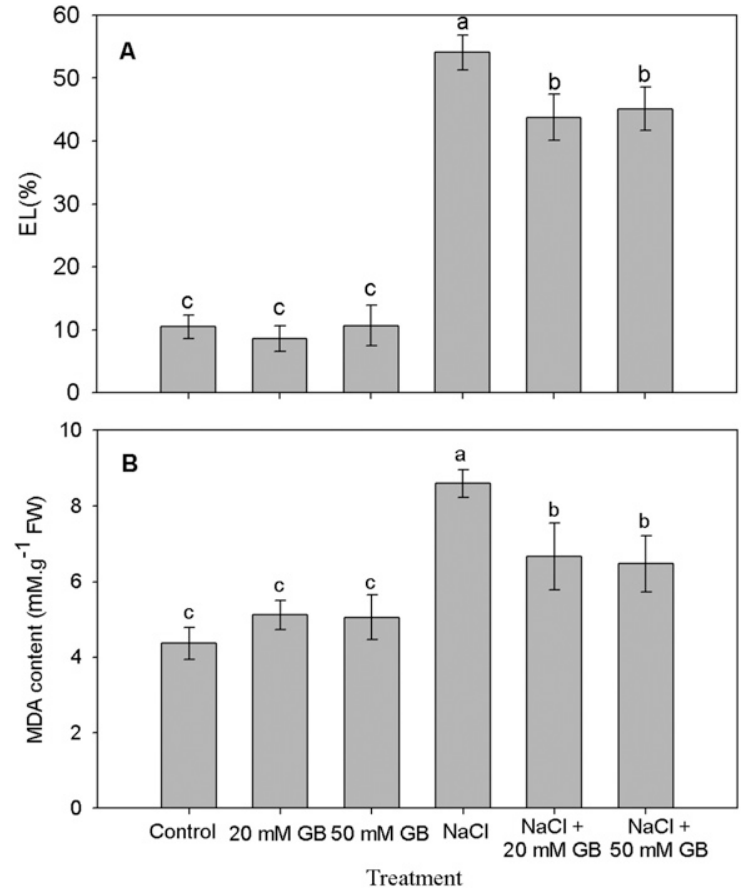

Fig. 4. Effects of glycine betaine (GB) on leaf electrolyte leakage (EL) (A) and lipid peroxidation (MDA) (B) of perennial ryegrass under salt stress or nonstress conditions. Vertical bars on the top indicate SD, and bars with the same letter indicate no significant difference at $P=0.05$.

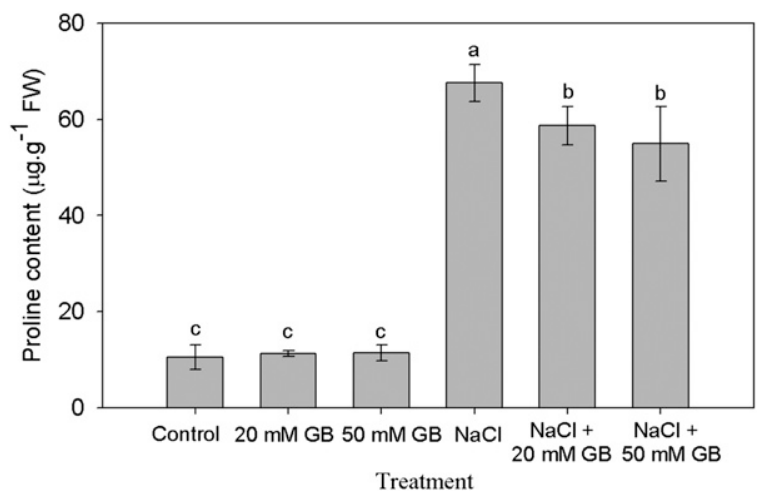

Fig. 5. Effects of glycine betaine (GB) on leaf proline content of perennial ryegrass under salt stress or non-stress conditions. Vertical bars on the top indicate SD, and bars with the same letter indicate no significant difference at $P=0.05$.

Table 2. Effect of exogenous glycine betaine (GB) on endogenous GB content of leaves, stems, and roots of perennial ryegrass under salt-stressed or non-stressed conditions. ${ }^{\mathrm{z}}$

\begin{tabular}{|c|c|c|c|c|c|c|}
\hline \multirow{3}{*}{$\begin{array}{l}\text { GB treatment } \\
(\mathrm{mm})\end{array}$} & \multicolumn{6}{|c|}{$\mathrm{NaCl}$ treatment $(\mathrm{mm})$} \\
\hline & 0 & 250 & 0 & 250 & 0 & 250 \\
\hline & \multicolumn{2}{|c|}{ Leaves $\left(\mathrm{mg} \cdot \mathrm{g}^{-1} \mathrm{DW}\right)$} & \multicolumn{2}{|c|}{ Stems (mg.g $\left.{ }^{-1} \mathrm{DW}\right)$} & \multicolumn{2}{|c|}{ Roots (mg.g $\left.{ }^{-1} \mathrm{DW}\right)$} \\
\hline 0 & $2.0 \mathrm{bC}^{\mathrm{y}}$ & $6.1 \mathrm{aB}$ & $2.1 \mathrm{bC}$ & $6.6 \mathrm{aB}$ & $0.8 \mathrm{aC}$ & $1.3 \mathrm{aC}$ \\
\hline 20 & $17.3 \mathrm{aB}$ & $8.8 \mathrm{bB}$ & $26.1 \mathrm{aB}$ & $18.4 \mathrm{aA}$ & $11.4 \mathrm{aB}$ & $10.5 \mathrm{aB}$ \\
\hline 50 & $25.8 \mathrm{aA}$ & $12.1 \mathrm{bA}$ & $40.7 \mathrm{aA}$ & $23.3 \mathrm{bA}$ & $37.3 \mathrm{aA}$ & $26.6 \mathrm{bA}$ \\
\hline
\end{tabular}

${ }^{\mathrm{z}}$ Data are expressed as means of four replicates $(n=4)$.

${ }^{y}$ Means in a column followed by the same upper-case letter for each organ are not significant; means in a row followed the same lower-case letters for each tissue are not significant at Fisher's protected least significant difference test at $P=0.05$.

$\mathrm{DW}=$ dry weight. in shoots (leaves plus stems) under both salt stress and nonstress conditions. The endogenous level of GB in leaves, stems, and roots was relatively higher in non- stressed plants than in salt-stressed ones under 20 and $50 \mathrm{~mm}$ of GB treatments.

The salt treatment alone reduced leaf SOD activity when compared with non-GB applied plants (Table 3). Under salt stress conditions, application of GB at 20 and $50 \mathrm{~mm}$ increased SOD activity by $24 \%$ and $44 \%$, CAT activity by $22 \%$ and $29 \%$, and APX activity by $32 \%$ and $31 \%$, respectively, when compared with non-GB treatment. Exogenous GB did not affect on SOD, CAT, and APX activities under non-salinity conditions (Table 3 ).

Salt stress caused a significant accumulation of $\mathrm{Na}^{+}$in leaves, stems, and roots (Table 4). Exogenous GB at $20 \mathrm{~mm}$ reduced the $\mathrm{Na}^{+}$content when compared with non-GB treatment under salinity conditions. Application of GB at $50 \mathrm{~mm}$ decreased the $\mathrm{Na}^{+}$content in leaves, stems, and roots under nonsalinity conditions and only in salt-stressed leaves (Table 4). Salt stress reduced $\mathrm{K}^{+}$content in leaves, stems, and roots (Table 4). The plants treated with $20 \mathrm{~mm}$ GB were able to retain higher amounts of $\mathrm{K}^{+}$in both leaves and stems when compared with non-GB-treated plants under salinity conditions. The plants treated with the higher concentration of GB $(50 \mathrm{~mm})$ had less $\mathrm{K}^{+}$ content in both leaves and stems than those treated with $20 \mathrm{~mm}$ GB or non-GB treatment under salinity conditions. Addition of $\mathrm{GB}$ reduced $\mathrm{K}^{+}$content in root tissues under both salt stress and non-stress conditions. Application of $50 \mathrm{~mm} \mathrm{~GB}$ also reduced in the absence of salt stress and caused a significant $(P=0.05)$ reduction of $\mathrm{K}^{+}$content in leaves and stems under both salinity and non-salinity conditions, except for that in non-stressed leaves, when compared with the non-GB treatments.

The $\mathrm{Na}^{+} / \mathrm{K}^{+}$ratio was calculated from the $\mathrm{Na}^{+}$and $\mathrm{K}^{+}$ content. Salt treatment increased the $\mathrm{Na}^{+} / \mathrm{K}^{+}$ratio in the leaves, stems, and roots (Table 4). Application of GB at $20 \mathrm{~mm}$ reduced the $\mathrm{Na}^{+} / \mathrm{K}^{+}$ratio in both leaves and stems when compared with non-GB treatment under salinity conditions. Addition of GB at 20 or $50 \mathrm{~mm}$ also enhanced $\mathrm{Na}^{+} / \mathrm{K}^{+}$ratio in the roots of saltstressed and non-stressed plants.

\section{Discussion}

A large amount of evidence suggested that increased accumulation levels of betaine in plants correlate with enhanced stress tolerance (Hasegawa et al., 2000). However, the GBs function only at relatively high levels in some plants under stress conditions. It has been shown that the synthesis and/or accumulation of GB in perennial ryegrass is relatively lower even under salinity stress conditions (Sima et al., 2009). Enhanced salt tolerance has been achieved by genetic engineering of GB synthesis with betaine aldehyde dehydrogenase and choline mono-oxygenase gene in perennial ryegrass (Bao et al., 2010). The results of this study indicated that exogenous application of GB alleviated detrimental effects of salt stress and may be a practical approach to improve salt stress tolerance in perennial ryegrass.

When exposed to salinity stress, the decrease in plant growth rate has 
Table 3. Effect of glycine betaine (GB) on activities of superoxide dismutase (SOD), catalase (CAT), and ascorbate peroxidase (APX) in leaves of perennial ryegrass under salt-stressed or non-stressed conditions. $^{z}$

\begin{tabular}{|c|c|c|c|c|c|c|}
\hline \multirow[b]{3}{*}{$\begin{array}{l}\text { GB treatment } \\
(\mathrm{mm})\end{array}$} & \multicolumn{6}{|c|}{$\mathrm{NaCl}$ treatment $(\mathrm{mm})$} \\
\hline & 0 & 250 & 0 & 250 & 0 & 250 \\
\hline & \multicolumn{2}{|c|}{$\begin{array}{c}\text { SOD }\left(\mathrm{U} \cdot \mathrm{min}^{-1} \cdot \mathrm{mg}^{-1}\right. \\
\text { protein })\end{array}$} & \multicolumn{2}{|c|}{$\begin{array}{l}\text { CAT }\left(\mathrm{U} \cdot \min ^{-1} \cdot \mathrm{mg}^{-1}\right. \\
\text { protein })\end{array}$} & \multicolumn{2}{|c|}{$\begin{array}{l}\mathrm{APX}\left(\mathrm{U} \cdot \mathrm{min}^{-1} \cdot \mathrm{mg}^{-1}\right. \\
\text { protein })\end{array}$} \\
\hline 0 & $46.6 \mathrm{aA}^{\mathrm{y}}$ & $32.6 \mathrm{bB}$ & $202.9 \mathrm{aA}$ & $162.3 \mathrm{aB}$ & $213.8 \mathrm{aA}$ & $148.7 \mathrm{aB}$ \\
\hline 20 & $45.7 \mathrm{aA}$ & $42.8 \mathrm{aA}$ & $191.0 \mathrm{aA}$ & $209.2 \mathrm{aA}$ & $199.0 \mathrm{aA}$ & $220.0 \mathrm{aA}$ \\
\hline 50 & $43.7 \mathrm{aA}$ & $45.0 \mathrm{aA}$ & $227.2 \mathrm{aA}$ & $229.4 \mathrm{aA}$ & $197.8 \mathrm{aA}$ & $215.9 \mathrm{aA}$ \\
\hline
\end{tabular}

${ }^{\mathrm{z}}$ Data are expressed as means of four replicates $(n=4)$.

${ }^{y}$ Means in a column followed by the same upper-case letter for each measurement are not significant; means in a row followed the same lower-case letters for each measurement are not significant at Fisher's protected least significant difference test at $P=0.05$.

Table 4. Effect of glycine betaine $(\mathrm{GB})$ on $\mathrm{Na}^{+}, \mathrm{K}^{+}$content, and $\mathrm{Na}^{+} / \mathrm{K}^{+}$ratio in leaves, stems, and roots of perennial ryegrass under salt-stressed or non-stressed conditions. ${ }^{\mathrm{z}}$

\begin{tabular}{|c|c|c|c|c|c|c|}
\hline \multirow{3}{*}{$\begin{array}{l}\text { GB treatment } \\
(\mathrm{mm})\end{array}$} & \multicolumn{6}{|c|}{$\mathrm{NaCl}$ treatment $(\mathrm{mm})$} \\
\hline & 0 & 250 & 0 & 250 & 0 & 250 \\
\hline & \multicolumn{2}{|c|}{ Leaves } & \multicolumn{2}{|c|}{ Stems } & \multicolumn{2}{|c|}{ Roots } \\
\hline & \multicolumn{6}{|c|}{$\mathrm{Na}^{+}$content $\left(\mathrm{mg} \cdot \mathrm{g}^{-1} \mathrm{DW}\right)$} \\
\hline 0 & $7.2 \mathrm{bA}^{\mathrm{z}}$ & $25.3 \mathrm{aA}$ & $8.5 \mathrm{bA}$ & $26.0 \mathrm{aA}$ & $6.0 \mathrm{bA}$ & $17.4 \mathrm{aA}$ \\
\hline 20 & $5.6 \mathrm{bB}$ & $20.9 \mathrm{aB}$ & $6.8 \mathrm{bAB}$ & $22.3 \mathrm{aB}$ & $5.7 \mathrm{bAB}$ & $13.9 \mathrm{aB}$ \\
\hline \multirow[t]{2}{*}{50} & $4.7 \mathrm{bC}$ & $21.3 \mathrm{aB}$ & $5.9 \mathrm{bB}$ & $24.8 \mathrm{aA}$ & $4.5 \mathrm{bB}$ & $15.5 \mathrm{aAB}$ \\
\hline & \multicolumn{6}{|c|}{$K^{+}$content $\left(m g \cdot g^{-1} D W\right)$} \\
\hline 0 & $29.2 \mathrm{aA}$ & $22.8 \mathrm{bB}$ & $27.8 \mathrm{aA}$ & $18.5 \mathrm{bB}$ & $9.3 \mathrm{aA}$ & $7.5 \mathrm{bA}$ \\
\hline 20 & $28.2 \mathrm{aA}$ & $24.8 \mathrm{bA}$ & $26.5 \mathrm{aB}$ & $21.4 \mathrm{bA}$ & $7.3 \mathrm{aB}$ & $4.3 \mathrm{bB}$ \\
\hline \multirow[t]{2}{*}{50} & $27.9 \mathrm{aA}$ & $19.6 \mathrm{bC}$ & $21.3 \mathrm{aC}$ & $15.6 \mathrm{bC}$ & $6.4 \mathrm{aB}$ & $4.7 \mathrm{bB}$ \\
\hline & \multicolumn{6}{|c|}{$\mathrm{Na}^{+} / \mathrm{K}^{+}$ratio } \\
\hline 0 & $0.25 \mathrm{bA}$ & $1.11 \mathrm{aA}$ & $0.30 \mathrm{bA}$ & $1.40 \mathrm{aA}$ & $0.64 \mathrm{bB}$ & $2.32 \mathrm{aB}$ \\
\hline 20 & $0.20 \mathrm{bB}$ & $0.84 \mathrm{aB}$ & $0.26 \mathrm{bA}$ & $1.04 \mathrm{aB}$ & $0.77 \mathrm{bA}$ & $3.24 \mathrm{aA}$ \\
\hline 50 & $0.17 \mathrm{bC}$ & $1.09 \mathrm{aA}$ & $0.28 \mathrm{bA}$ & $1.59 \mathrm{aA}$ & $0.70 \mathrm{bAB}$ & $3.32 \mathrm{aA}$ \\
\hline
\end{tabular}

${ }^{\mathrm{z}}$ Data are expressed as means of four replicates $(n=4)$.

${ }^{\mathrm{y}}$ Means in a column followed by the same upper-case letter for each measurement are not significant; means in a row followed the same lower-case letters for each measurement are not significant at Fisher's protected least significant difference test at $P=0.05$.

$\mathrm{DW}=$ dry weight.

been attributed to the inhibition of the absorption of available water, excessive accumulation of $\mathrm{Na}^{+}$or $\mathrm{Cl}^{-}$, inadequate uptake of an essential nutrient, and accumulation of toxic intermediate compounds such as ROS (Rodriguez et al., 2004). The VSGR and FW of shoot and root were higher in GB-treated plants than non-GB-treated plants under salinity condition, suggesting that exogenous GB could alleviate the detrimental effect of salt stress on the growth of perennial ryegrass. Exogenous GB alleviated the inhibitory effect of salt stress, whereas it inhibited the plant vertical growth under non-salinity conditions. It seems that addition of GB alone slightly affects the growth and the protective effect of GB is apparent only under conditions of salt stress (Meloni and Martínez, 2009).

Water status is highly sensitive to salinity and therefore is dominant in determining the plant responses to stress (Stepien and Klobus, 2006). It is well known that salt stress reduces root hydraulic conductivity, resulting in decreased water flow from roots to shoots, even in osmotically adjusted plants (Prisco, 1980). The transpiration rate of plants is coupled with the photosynthesis, and the inhibition of transpiration is a reliable and quick measure of toxic effects of salt (Trapp et al., 2000, 2008). The decrease in relative $\operatorname{Tr}$ and leaf RWC in salt-stressed plants suggested that $\mathrm{NaCl}$ decreased the water flow from roots to shoots and caused a toxic effect on the growth of perennial ryegrass. The decrease in water flow resulting from salt stress may cause a decline in leaf water content, which would result in stomatal closure to maintain their water status (Prisco, 1980). Our results showed that GB application increased RWC and relative $\mathrm{Tr}$ in salt-stressed plants. This suggested that GB could increase the hydraulic conductivity, which may enhance the water flow from roots to shoots and eventually increase the RWC and transpirations rate under salinity stress (Prisco, 1980). Another potential action of $\mathrm{NaCl}$ on transpiration may result from direct inhibition of stomatal opening by apoplastic $\mathrm{Na}^{+}$concentration, as suggested by the studies of Aster tripolium (Perera et al., 1994).

Chl content in GB-treated plants under salt stress was higher than that in the plants treated with salt without GB. This result suggested that GB may play a specific role in dealing with the salt stress-induced senescence in leaves (Demiral and Türkan, 2006). Likewise, Mäkelä et al. (2000) also found an increase in Chl content in tomato plants under drought or salinity by means of foliar application of GB. Although other reports indicated that the GBinduced alleviation of $\mathrm{Chl}$ content decline was attributed to enhanced activity of the Chl-degrading enzyme chlorophyllase (Mishra and Sharma, 1994), increased cytokinin concentration, which retards Chl degradation (Shetty et al., 1992), decreased toxic ion, especially sodium concentration, increased some ions as $\mathrm{Mg}^{2+}$, is which needed for Chl synthesis, and increased potassium concentration (Shaddad et al., 1999).

Plants usually accumulate compatible osmolytes such as GB and proline in response to salt stress (Zhu, 2001). Increased accumulation of proline in stressed plants may be an adaptation to compensate for the energy for growth and survival and thereby help the plant tolerate stress, as reported in Crotalaira striata (Chandrasekhar and SandhyaRani, 1996) and in spinach leaves [Spinacia oleracea (Ozturk and Demir, 2003)]. A higher level of proline accumulation resulting from GB application under salinity has been found in rice (Demiral and Türkan, 2006) and tomato (Heuer, 2003). However, our results showed that salt stress induced a higher level of proline content, whereas GB application reduced the proline accumulation when compared with salt treatment without GB, suggesting that proline 
accumulation in perennial ryegrass is just a symptom of salt stress rather than a cause of tolerance (Ashraf, 1989). Endogenous GB level increased with the increasing level of exogenous GB application in salt-stressed and non-stressed plants to a greater extent in shoots than that in roots. These results indicated that GB could be taken up by perennial ryegrass and translocated to various organs from the original site of application (Park et al., 2006). The endogenous GB level in non-stressed plants increased more than salt-stressed ones, suggesting its long-distance transport of GB may be phloem mobile, which is driven by the transpiration stream because the relative $\mathrm{Tr}$ of non-stressed plants is higher that that of saltstressed ones (Mäkelä et al., 1996).

Alleviating the effect of exogenous betaine on salt stress is considered to be involved in scavenging free radicals and in protecting antioxidant enzymes (Hoque et al., 2006). In the present study, salt stress caused a reduction in SOD activity; exogenous application of GB enhanced its activity. These results suggested that GB-induced enhancement in SOD activity may have protected membrane stability from saltinduced oxidative damage. This is supported by a previous study by Nawaz and Ashraf (2010) who found that GB-treated wheat plants exhibited increased SOD activity under salinity stress. In addition to SOD, a higher level of protection against oxidative damage should require fast removal of $\mathrm{H}_{2} \mathrm{O}_{2}$ by other scavenging systems, thus minimizing $\mathrm{H}_{2} \mathrm{O}_{2}$ toxicity and the formation of the highly toxic $\mathrm{OH}^{-}$(Mittler, 2002). CAT and APX are the major $\mathrm{H}_{2} \mathrm{O}_{2}$ scavenging enzymes in plants, which are involved in the degradation of $\mathrm{H}_{2} \mathrm{O}_{2}$ into water and oxygen (Nakano and Asada, 1981; Parvaiz and Satyawati, 2008). The results in this study revealed that CAT and APX activity decreased in perennial ryegrass in response to salt stress, whereas exogenous application of GB led to a considerable increase in CAT and APX activity under salt stress (Table 3). These results agreed well with those of Demiral and Türkan (2006), who observed that betaine increased CAT and APX activity under stress conditions. These results suggested that exogenous $\mathrm{GB}$ could contribute to detoxifying $\mathrm{H}_{2} \mathrm{O}_{2}$ by enhancing SOD, CAT, and APX activities under salt stress.

Electrolyte leakage and membrane lipid peroxidation in higher plants are generally indicated by free radical-induced membrane damage or deterioration when plants are subjected to environmental stresses (Allen et al., 1997). Our results showed that exogenous GB lowered the EL and MDA in salt-stressed leaves of perennial ryegrass. These results suggested that GB alleviated lipid peroxidation and facilitated the maintenance of membrane functions under salinity conditions. This facilitation could be attributed to the GB-induced antioxidant responses that protect the plant from oxidative damage (Hoque et al., 2007; Meloni and Martínez, 2009).

Salt stress commonly caused a higher accumulation of $\mathrm{Na}^{+}$ and a massive $\mathrm{K}^{+}$efflux from plant tissues (Shabala et al., 2003), which affects cytosolic $\mathrm{K}^{+}$homeostasis and plant survival (Cuin et al., 2003). Therefore, maintenance of high cytosolic $\mathrm{K}^{+}$concentrations and a proper $\mathrm{Na}^{+} / \mathrm{K}^{+}$balance is considered to be one of the most fundamental salt tolerance mechanisms in plants (Meloni and Martínez, 2009). In this work, NaCl-stressed perennial ryegrass significantly accumulated more $\mathrm{Na}^{+}$and less $\mathrm{K}^{+}$than non-stressed plants, which led to a higher $\mathrm{Na}^{+} / \mathrm{K}^{+}$ratio; this may be the result of possible antagonism between $\mathrm{K}^{+}$and $\mathrm{Na}^{+}$(Gómez et al., 1996). Conversely, the application of $20 \mathrm{~mm}$ of $\mathrm{GB}$ reduced $\mathrm{Na}^{+}$ concentration and increased $\mathrm{K}^{+}$concentration when compared with non-GB treatment under salinity conditions. These results indicated that GB may play a role in maintaining cytosolic $\mathrm{K}^{+}$ homeostasis by suppressing $\mathrm{Na}^{+}$-enhanced apoplastic flow to reduce $\mathrm{Na}^{+}$uptake (Sobahan et al., 2009) and mitigating $\mathrm{NaCl}$ induced $\mathrm{K}^{+}$efflux from the cell (Meloni and Martínez, 2009). Reduction of $\mathrm{Na}^{+}$accumulation and mitigation of $\mathrm{NaCl}$-induced $\mathrm{K}^{+}$loss in salt-stressed plants by exogenous application of GB have also been reported in tomato leaves (Heuer, 2003), rice seedlings (Rahman et al., 2002), and barley (Cuin and Shabala, 2007). Addition of $50 \mathrm{~mm}$ of GB further reduced $\mathrm{K}^{+}$concentration in stems and roots of perennial ryegrass under both salinity and non-salinity conditions, suggesting that GB may be able to counteract salt stress effects and also may be toxic to the plants if GB is added in high concentrations because the concentration of betaine, which maximally mitigate salt stress was reported to be $\approx 10$ to $30 \mathrm{~mm}$ (Roy et al., 1993).

In summary, this study indicated that exogenous GB was effective in ameliorating the adverse effects of salinity stress on perennial ryegrass with proper concentrations. The beneficial effect of exogenously applied GB to plants under salinity stress may be attributed to its protective effect on peroxidation-linked membrane deterioration and scavenging free radicals and the maintenance of $\mathrm{K}^{+}$homeostasis by preventing $\mathrm{NaCl}$-induced $\mathrm{K}^{+}$loss.

\section{Literature Cited}

Allen, D.J., I.F.M. Kee, P.K. Farage, and N.R. Baker. 1997. Analysis of the limitation to $\mathrm{CO}_{2}$ assimilation to exposure of leaves of two Brassica napus cultivars to UV-B. Plant Cell Environ. 20:633640.

Apel, K. and H. Hirt. 2004. Reactive oxygen species: Metabolism, oxidative stress, and signal transduction. Annu. Rev. Plant Biol. 55:373-399.

Ashraf, M. 1989. The effect of $\mathrm{NaCl}$ on water relations, chlorophyll and protein and proline contents of two cultivars of blackgram (Vigna mungo L.). Plant Soil 119:205-210.

Bao, Y., R. Zhao, F. Li, W. Tang, and L. Han. 2010. Simultaneous expression of Spinacia oleracea chloroplast choline monooxygenase (CMO) and betainea aldehyde dehydrogenase (BADH) genes contribute to dwarfism in transgenic Lolium perenne. Plant Mol. Biol. Rpt. 10:1-10.

Barrs, H.D. and P.E. Weatherly. 1962. A re-examination of the relative turgidity technique for estimating water deficits in leaves. Aust. J. Biol. Sci. 15:413-428.

Bates, L.S., R.P. Waldren, and I.D. Tear. 1973. Rapid determination of free proline for water-stress studies. Plant Soil 39:205-207.

Bohnert, H.J., D.E. Nelson, and J.E. Jensen. 1995. Adaptations to environmental stresses. Plant Cell 7:1099-1111.

Bradford, M.M. 1976. A rapid and sensitive method for quantitation of microgram quantities of protein utilizing the principle of proteindye-binding. Anal. Biochem. 72:248-254.

Chance, B. and A.C. Maehly. 1955. Assay catalases and peroxidases. Methods Enzymol. 2:764-768.

Chandrasekhar, K.R. and S. SandhyaRani. 1996. Salinity induced chemical changes in Crotalaria striata DC plants. Indian J. Plant Physiol. 1:44-48.

Cuin, T.A., A.J. Miller, S.A. Laurie, and R.A. Leigh. 2003. Potassium activities in cell compartments of salt-grown barley leaves. J. Expt. Bot. 54:657-661.

Cuin, T.A. and S. Shabala. 2005. Exogenously supplied compatible solutes rapidly ameliorate $\mathrm{NaCl}$-induced potassium efflux from barley roots. Plant Cell Physiol. 46:1924-1933.

Cuin, T.A. and S. Shabala. 2007. Potassium efflux channels mediate arabidopsis root responses to reactive oxygen species and the 
mitigating effect of compatible solutes. Plant Cell Environ. 7:875885.

Demiral, T. and I. Türkan. 2006. Exogenous glycinebetaine affects growth and proline accumulation and retards senescence in two rice cultivars under $\mathrm{NaCl}$ stress. Environ. Exp. Bot. 56:72-79.

Dhindsa, R.S., P. Plumb-Dhindsa, and T.A. Thorpe. 1981. Leaf senescence: Correlated with increased levels of membrane permeability and lipid peroxidation, and decreased levels of superoxide dismutase and catalase. J. Expt. Bot. 32:93-101.

Foyer, C.H. and G. Noctor. 2000. Oxygen processing in photosynthesis: A molecular approach. New Phytol. 146:359-388.

Fu, J., J. Fry, and B. Huang. 2004. Minimum water requirements and stress and indicators of four turfgrasses subjected to deficit irrigation. HortScience 39:1740-1744.

$\mathrm{Fu}$, J. and B. Huang. 2001. Involvement of antioxidants and lipid peroxidation in the adaptation of two cool season grasses to localized drought stress. Environ. Exp. Bot. 45:105-114.

Gómez, I., J.N. Pedreño, R. Moral, M.R. Iborra, G. Palacios, and J. Mataix. 1996. Salinity and nitrogen fertilization affecting the macronutrient content and yield of sweet pepper plants. J. Plant Nutr. 19:353-359.

Grieve, C.M. and S.R. Grattan. 1983. Rapid assay for the determination of water soluble quaternary ammonium compounds. Plant Soil 70:303-307.

Hamdia, M.A. and M.A.K. Shaddad. 2010. Salt tolerance of crop plants. J. Stress Physiol. Biochem. 6:64-90.

Hasegawa, P.M., R.A. Bressan, J. Zhu, and H.J. Bohnert. 2000. Plant cellular and molecular response to high salinity. Annu. Rev. Plant Physiol. Plant Mol. Biol. 51:463-499.

Heath, R.L. and L. Packer. 1968. Photoperoxidation in isolated chloroplasts. I. Kinetics and stoichiometry of fatty acid peroxidation. Arch. Biochem. Biophys. 125:189-198.

Heuer, B. 2003. Influence of exogenous application of proline and glycinebetaine on growth of salt-stressed tomato plants. Plant Sci. 165:693-699.

Hiscox, T.D. and G.F. Israelstam. 1979. A method for the extraction of chlorophyll from leaf tissues without maceration. Can. J. Bot. 57: 1332-1334.

Hoagland, D.R. and D.I. Arnon. 1950. The water-culture method for growing plants without soil. California Agr. Expt. Sta. Circ. 347:132.

Hoque, M.A., M.N.A. Banu, E. Okuma, K. Amako, Y. Nakamura, Y. Shimoishi, and Y. Murata. 2007. Exogenous proline and glycinebetaine increase $\mathrm{NaCl}$-induced ascorbate-glutathione cycle enzyme activities, and proline improves salt tolerance more than glycinebetaine in tobacco Bright Yellow-2 suspension-cultured cells. J. Plant Physiol. 164:1457-1468.

Hoque, M.A., E. Okuma, M.N.A. Banu, Y. Nakamura, Y. Shimoishi, and Y. Murata. 2006. Exogenous proline mitigates the detrimental effects of salt stress more than exogenous betaine by increasing antioxidant enzyme activities. J. Plant Physiol. 164:553-561.

Hossain, M. and M. Fujita. 2010. Evidence for a role of exogenous glycinebetaine and proline in antioxidant defense and methylglyoxal detoxification systems in mung bean seedlings under salt stress. Physiol. Mol. Biol. Plants 16:19-29.

Huang, B. and L. Liu. 2009. Physiological responses of creeping bentgrass to heat stress affected by phosphonate fungicide application. Intl. Turfgrass Soc. Res. J. 11:799-806.

Lopez, C.M.L., H. Takahashi, and S. Yamazaki. 2002. Plant-water relations of kidney bean plants treated with $\mathrm{NaCl}$ and foliarly applied glycinebetaine. J. Agron. Crop Sci. 188:73-80.

Mäkelä, P., J. Karkkainen, and S. Somersalo. 2000. Effect of glycine betaine on chloroplast ultrastructure, chlorophyll and protein content, and RuBPCO activities in tomato grown under drought or salinity. Biol. Plant. 43:471-475.

Mäkelä, P., M. Kontturi, E. Pehu, and S. Somersalo. 1999. Photosynthetic response of drought- and salt-stressed tomato and turnip rape plants to foliar-applied glycinebetaine. Physiol. Plant. 105:45-50.
Mäkelä, P., P. Peltonen-Sainio, K. Jokinen, E. Pehu, H. Setala, R. Hinkkanen, and S. Somersalo. 1996. Uptake and translocation of foliar-applied glycinebetaine in crop plants. Plant Sci. 121:221-230.

Meloni, D.A. and C.A. Martínez. 2009. Glycinebetaine improves salt tolerance in vinal (Prosopis ruscifolia Griesbach) seedlings. Braz. J. Plant Physiol. 21:233-241.

Meloni, D.A., M.A. Oliva, C.A. Martinez, and J. Cambraia. 2003. Photosynthesis and activity of superoxide dismutase, peroxidase and glutathione reductase in cotton under salt stress. Environ. Exp. Bot. 49:69-76.

Mishra, S.N. and I. Sharma. 1994. Putrescine as a growth inducer and as a source of nitrogen for mustard seedlings under sodium chloride salinity. Indian J. Expt. Physiol. 32:916-918.

Mittler, R. 2002. Oxidative stress, antioxidants and stress tolerance. Trends Plant Sci. 7:405-410.

Nakano, Y. and K. Asada. 1981. Hydrogen peroxide is scavenged by ascorbate specific peroxidase in spinach chloroplasts. Plant Cell Physiol. 22:867-880.

Nawaz, K. and M. Ashraf. 2010. Exogenous application of glycinebetaine modulates activities of antioxidants in maize plants subjected to salt stress. J. Agron. Crop Sci. 196:28-37.

Ozturk, L. and Y. Demir. 2003. Effects of putrescine and ethephon on some oxidative stress enzyme activities and proline content in salt stressed spinach leaves. Plant Growth Regulat. 40:89-95.

Park, E.J., Z. Jeknic, and T.H.H. Chen. 2006. Exogenous application of glycinebetaine increases chilling tolerance in tomato plants. Plant Cell Physiol. 47:706-714.

Parvaiz, A. and S. Satyawati. 2008. Salt stress and phyto-biochemical responses of plants - A review. Plant Soil Environ. 54:89-99.

Perera, L.K.R.R., T.A. Mansfield, and A.J.C. Malloch. 1994. Stomatal responses to sodium ions in Aster tripolium: A new hypothesis to explain salinity regulation in above-ground tissues. Plant Cell Environ. 17:335-340.

Prisco, J.T. 1980. Alguns aspectos da fisiologia do "stress" salino. Revista Brasileira de Botânica 3:85-94.

Rahman, M., H. Miyake, and Y. Takeoka. 2002. Effects of exogenous glycine betaine on growth and ultraestructure of salt-stressed rice seedlings (Oryza sativa L.). Plant Prod. Sci. 5:33-44.

Raza, S.H., H.R. Athar, M. Ashraf, and A. Hameed. 2007. Glycinebetaineinduced modulation of antioxidant enzymes activities and ion accumulation in two wheat cultivars differing in salt tolerance. Environ. Exp. Bot. 60:368-376.

Rodriguez, A.A., A.R. Cordoba, L. Ortega, and E. Taleisnik. 2004. Decreased reactive oxygen species concentration in the elongation zone contributes to the reduction in maize leaf growth under salinity. J. Expt. Bot. 41:1383-1390.

Roy, D., N. Basu, A. Bhunia, and S.K. Banerjee. 1993. Counteraction of exogenous L-proline with. $\mathrm{NaCl}$ in salt-sensitive cultivar of rice. Biol. Plant. 35:69-72.

Sakamoto, A. and N. Murata. 2002. The role of glycine betaine in the protection of plants from stress: Clues from transgenic plants. Plant Cell Environ. 25:163-171.

Shabala, S.N., L. Shabala, and E. Volkenburgh. 2003. Effect of calcium on root development and root ion fluxes in salinised barley seedlings. Funct. Plant Biol. 30:507-514.

Shaddad, M.A., A.F. Radi, A.M. Abdel-Rahman, and M.M. Azooz. 1999. Response of seeds of Lupinus termis and Vicia faba to the interactive effect of salinity and ascorbic acid or pyridoxine. Plant Soil 122:177-183.

Shetty, K., G.A. Shetty, Y. Nakazaki, K. Yoshioka, Y. Asano, and K. Oosawa. 1992. Stimulation of benzyladenine induced in vitro shoot organogensis in Cucumus melo L. by proline, salicylic acid and aspirin. Plant Sci. 84:193-199.

Sima, N.A.K.K., H. Askari, H.H. Mirzaei, and M. Pessarakli. 2009. Genotype-dependent differential responses of three forage species to calcium supplement in saline conditions. J. Plant Nutr. 32:579-597. Sobahan, M.A., C.R. Arias, E. Okuma, Y. Shimoishi, Y. Nakamura, Y. Hirai, I.C. Mori, and Y. Murata. 2009. Exogenous proline and 
glycinebetaine suppress apoplastic flow to reduce $\mathrm{Na}^{+}$uptake in rice seedlings. Biosci. Biotechnol. Biochem. 73:2037-2042.

Stepien, P. and G. Klobus. 2006. Water relations and photosynthesis in Cucumis sativus L. leaves under salt stress. Biol. Plant. 50:610-616. Subbarao, G.V., R.M. Wheeler, L.H. Levine, and G.W. Stutte. 2001. Glycinebetaine accumulation, ionic and water relations of red-beet at contrasting levels of sodium supply. J. Plant Physiol. 158:767-776.

Trapp, S., D. Feificova, N.F. Rasmussen, and P. Bauer-Gottwein. 2008. Plant uptake of $\mathrm{NaCl}$ in relation to enzyme kinetics and toxic effects. Environ. Exp. Bot. 64:1-7.
Trapp, S., K.C. Zambrano, K.O. Kusk, and U. Karlson. 2000. A phytotoxicity test using transpiration of willows. Arch. Environ. Contamination Toxciology 39:154-160.

Yang, X. and C. Lu. 2005. Photosynthesis is improved by exogenous glycinebetaine in salt-stressed maize plants. Physiol. Plant. 124:343352.

$\mathrm{Yu}, \mathrm{X}$., J. Gu, and L. Li. 2008. Assimilation and physiological effects of ferrocyanide on weeping willows. Ecotoxicol. Environ. Saf. 71:609-615.

Zhu, J. 2001. Plant salt tolerance. Trends Plant Sci. 6:66-71. 